\title{
Colonic muscle enhances the production of interleukin-1 $\beta$ messenger RNA in experimental colitis
}

I Khan, F M Al-Awadi

\begin{abstract}
Background-Inflammatory bowel diseases are accompanied by alterations in the contractile function of colonic muscle. Whether these changes are also accompanied by the production of interleukin-1 $\beta$ (IL-1ß) mRNA remains unknown.

Aims-To investigate the profile of IL-1 mRNA in the colonic muscle of rats with acetic acid induced colitis.

Methods-Colitis was induced by intrarectal administration of $1 \mathrm{ml}$ of $4 \%$ acetic acid $8 \mathrm{~cm}$ from anal margin. Myeloperoxidase activity was used as a marker of inflammation in the colon. RNA was extracted from colonic muscle and was used to amplify the level of IL-1 $\beta$ mRNA with a reverse transcription coupled polymerase chain reaction (RT-PCR) method developed in this study.

Results-Colonic muscle exhibited constitutive expression of IL-1 $\beta$ mRNA. The level was enhanced significantly, one, two, and five days after acetic acid administration. On day 7 after treatment, the level of IL-1 $\beta$ mRNA had returned baseline values. This profile of IL-1 $\mathrm{mRNA}$ was consistent with myeloperoxidase activity.


ator of the changes in muscle function in this model of colitis.
\end{abstract}

(Gut 1997; 40: 307-312)

Keywords: acetic acid, colitis, inflammation, muscle contraction, interleukin- $1 \beta$, polymerase chain reaction.

The damage in inflammatory bowel diseases is primarily focused on the mucosa and submucosa, but the functions of muscle layers are also affected. Although the aetiology of these diseases remains unknown, they are regarded as inflammatory responses to a wide variety of unidentified antigens. ${ }^{1}$ The diseases are characterised by changes in muscle function, ${ }^{2}$ alterations in the release of neurotransmitters, ${ }^{3}$ and increases in cytokine concentration. ${ }^{4}$ The molecular basis of the physiological changes and their mediators remains unknown.

Interleukin-1 $\beta$ (IL-1 $\beta$ ) is a pleiotropic molecule $^{5}$ which regulates many events that occur in inflammation. For example, it has been implicated as a mediator of inflammation induced changes in nerve cell function ${ }^{6}$ and in vitro induction of proliferation of human muscle cells. ${ }^{7}$ In vascular muscle it causes rapid relaxation. ${ }^{8}$ Although mucosal expression of
IL-1 $\beta$ has been shown in many studies during colitis, it is not known whether colonic muscle also elaborates the expression of IL-1 $\beta$. Because muscle contractility is decreased during colitis, ${ }^{9}$ we hypothesised that expression of IL$1 \beta$ is increased in colonic muscle during colitis. To identify the presence of IL-1 $\beta$ in colonic muscle, the IL-1 $\beta$ mRNA during colitis induced in rats by acetic acid was measured as an index of gene activity. This required the development of a reliable competitive reverse transcription coupled polymerase chain reaction (RT-PCR) method.

\section{Methods}

\section{INDUCTION OF COLITIS}

Male Sprague-Dawley rats (Faculty of Medicine, Kuwait University) weighing 170-180 g were used. Colitis was induced by instilling 1 $\mathrm{ml}$ of $4 \%$ acetic acid intrarectality at $8 \mathrm{~cm}$ from anal margin. ${ }^{10}$ Animals were killed by cervical dislocation on one, two, five, and seven days after administration of acetic acid. Colon from the site of inflammation was removed, cleaned with phosphate buffered saline (PBS), the mucosa scraped off, and the muscle frozen in liquid nitrogen and stored at $-70^{\circ} \mathrm{C}$. The muscle contained both longitudinal and circular layers. Inflammation in each animal was monitored by estimation of myeloperoxidase activity $^{911}$ in the whole colonic tissue taken from the site of acetic acid application (not in muscle layers separately). Activity of myeloperoxidase was represented as units $/ \mathrm{min} / \mathrm{g}$ of the whole colonic tissue and is defined as the conversion of $1 \mu \mathrm{mol}$ of $\mathrm{H}_{2} \mathrm{O}_{2} / \mathrm{min} / \mathrm{g}$ tissue at room temperature.

\section{INTERLEUKIN- $1 \beta$ mRNA ESTIMATION}

Total cellular RNA was extracted from colonic muscle by the guanidinium isothiocyanatecesium chloride centrifugation method. ${ }^{12}$ Integrity of the total RNA was analysed electrophoretically on formaldehyde agarose $(1.4 \%)$ gel. ${ }^{13}$ Aliquots $(5 \mu \mathrm{g})$ of total RNA were annealed with $250 \mathrm{ng}$ of oligo dT primer (Promega) by heating at $75^{\circ} \mathrm{C}$ for 10 minutes followed by their slow cooling to $37^{\circ} \mathrm{C}$. Reverse transcription was carried out using 5 units of avian myeloma virus reverse transcriptase (Pharmacia) and 20 units of RNA guard (Pharmacia) as described earlier ${ }^{14}$ in a total volume of $50 \mu \mathrm{l}$. An aliquot of 5-10 $\mu \mathrm{l}$ from this cDNA was amplified routinely in these 
experiments using the following PCR amplification conditions: denaturation $94^{\circ} \mathrm{C} \times 30$ seconds, annealing $50^{\circ} \mathrm{C} \times 30$ seconds, and extension $74^{\circ} \mathrm{C} \times 60$ seconds. $\mathrm{MgCl}_{2}$ was used at a concentration of $1.5 \mathrm{mmol} / /$. The PCR amplification reaction was carried out in the presence of $50 \mathrm{pmol}$ of each primer and 2.5 units of Amplitaq enzyme (Perkin-Elmer) in a thermocycler (Perkin-Elmer; Gene Amp PCR System No 9600). The PCR reaction conditions were the same as recommended by the manufacturer (Perkin-Elmer). The PCR products were routinely analysed by electrophoresis on $2 \cdot 4 \%$ agarose gel, ${ }^{13}$ staining with ethidium bromide, and photography with a gel documentation system (Stratagene). Basic protocols of PCR and reverse transcription procedures were the same as described earlier. ${ }^{14-16}$ All experiments were carried out under RNase free conditions and solutions and glassware were made RNase free by treatment with diethylpyrocarbonate (DEPC; Sigma) or by autoclaving. Heat sensitive solutions were made in DEPC treated and autoclaved water which were subsequently filtered through 0.45 $\mu$ Millipore filters.

\section{DEVELOPMENT OF THE COMPETITIVE PCR} METHOD

PR1 and PR2 primers were designed based on the available complementary DNA sequences of human and mouse IL-1 $\beta^{17} 18$ and human interleukin-6 (IL-6). ${ }^{19}$ The upstream primer, PR1 (5'-ACAAAATACCTGTGGCCTTGG GAACCTTCCAAAGATGGCTGA-3') consisted of upstream primers of IL-1 $\beta$ (in bold) and human IL-6 (normal font). Similarly the downstream primer PR2 (5'-GAGGTGCTG ATGTACCAGTTGCAGGCTGGACTGC AGGAAC-3') was made up of downstream primers of IL-1 $\beta$ (in bold) and human IL-6 (normal font). Using PR1 and PR2 primers, a 391 base pair fragment (designated as ICOM1) was amplified from human total RNA by RT-PCR, which was purified from gel ${ }^{13}$ and quantitated spectrophotometrically (DU-70, Beckman). Thus the primers PR1 and PR2 were used only to create the sites of IL-1 $\beta$ primers PR3 (5'-ACAAAATACCTGTGGCCTTGG-3') and PR4 (5'-GAGGTGCTGATGTACCAGTTG -3') in the human IL-6 fragment. The purified ICOM-1 competitive control was used to spike the RNA samples to quantify the level of IL-1 $\beta$ mRNA using PR3 and PR4 primers. Although the primers PR3 and PR4 were designed using mouse and human cDNA sequences, ${ }^{17} 18$ they also amplified IL-1 $\beta$ mRNA from rat samples. These primers were obtained from Genosys, UK.

ANALYSIS OF DATA

Ratios IL-1 $\beta$ :ICOM-1 and IL-1 $\beta$ : $\beta$-subunit isoform were calculated from the areas of the bands scanned on a densitometer (Pharmacia, LKB) from the negatives. The changes in the level of IL-1 $\beta$ were calculated with respect to the control ratio taken as 100 . A value of $\mathrm{p}<0.05$ was considered to be significant.

\section{Results}

ESTIMATION OF MYELOPEROXIDASE ACTIVITY Acetic acid causes epithelial erosion, loss of crypts, infiltration of inflammatory cells, bleeding, and diarrhoea, which were apparent one, two, and five days after treatment. The gut $\Omega$ looked red and inflamed after one and two days of acetic acid but apparently normal after seven $\stackrel{\vec{\rho}}{\vec{F}}$ days (data not shown). Colitis was assessed by흐 measuring the myeloperoxidase level in a seg-듬 ment of whole colon taken from the site of $\frac{\bar{s}}{7}$ inflammation. The mean (SD) level of myelo- $\stackrel{\mathbb{D}}{\varrho}$ peroxidase activity (units $/ \mathrm{min} / \mathrm{g})(1.4(0.9))$ in the control rats was increased significantly after $\overrightarrow{0}$ one $(4 \cdot 5(1 \cdot 1))$, two $(12 \cdot 2(2 \cdot 5))$, and five $\left(29^{\circ}\right.$ (4)) days of acetic acid administration. How $-\vec{\omega}$ ever, after seven days myeloperoxidase activity (4 (0.9)) was not significantly different from the basal level. The level of myeloperoxidase + activity after five days of acetic acid adminis- $\omega$ tration was not suppressed by indomethacin treatment (data not shown).

DEVELOPMENT OF THE RT-PCR METHOD

To estimate the level of IL-1 $\beta$ mRNA, we developed the present competitive RT-PCR $\overrightarrow{0}$

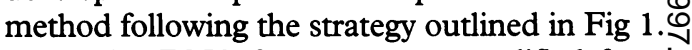
A $391 \mathrm{bp}$ DNA fragment was amplified from human total RNA using PR1 and PR2 primers (Fig 2, lane 2). This fragment was designated as ICOM-1 and was used as a competitiveô control for the quantitation of IL-1 $\beta$ mRNA $\stackrel{\circ}{\circ}$ levels in the colonic RNA samples.

Although we used PR1 and PR2 to generate the sites of PR3 and PR4 primers in the IL-6 fragment for optimisation of the PCR con-o ditions, in linear range amplification primerso PR3 and PR4 were used. Serially diluted ICOM-1 samples $\left(3 \cdot 125,6 \cdot 25,12 \cdot 5,25,50, \frac{5}{3}\right.$ and $100 \mathrm{ng}$ ICOM-1 respectively in lanes $6,5$. 4, 3, 2, and 1) amplified using PR3 and PR4윽

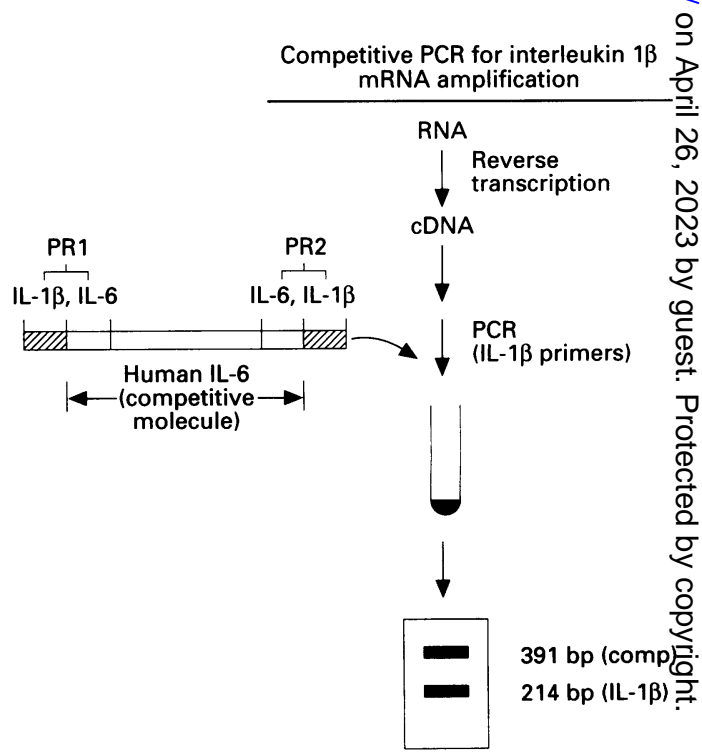

Figure 1: Strategy of the competitive RT-PCR method developed for the quantitation of interleukin- $1 \beta m R N A$. The competitive control molecule is a human IL-6 cDNA fragment flanked by the sites of upstream (PR1) and downstream (PR2) primers each containing sites of human IL-6 (open rectangles) and of IL-1 $\beta$ (hatched rectangles) primers; comp $=$ competitive control. 


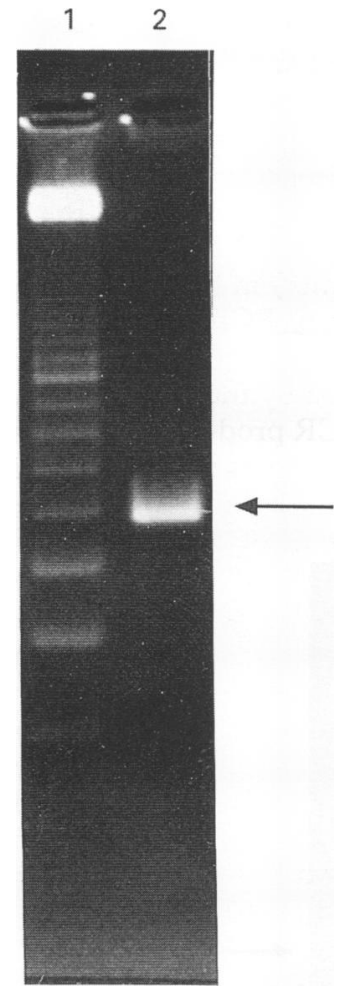

Figure 2: PCR amplification of the competitive control, 391 bp fragment (lane 2) amplified from human total $R N A$ using primers $P R 1$ and PR2. Lane 1 contains a $100 \mathrm{bp}$ DNA ladder (Pharmacia). The position of ICOM-1 is shown by the arrow.

primers showed a concentration dependent amplification of ICOM-1 (Fig 3). These serially diluted samples were mixed with 500 ng reverse transcribed rat total RNA and were amplified using PR3 and PR4 primers (Fig 4). The level of ICOM-1 exhibited a concen-

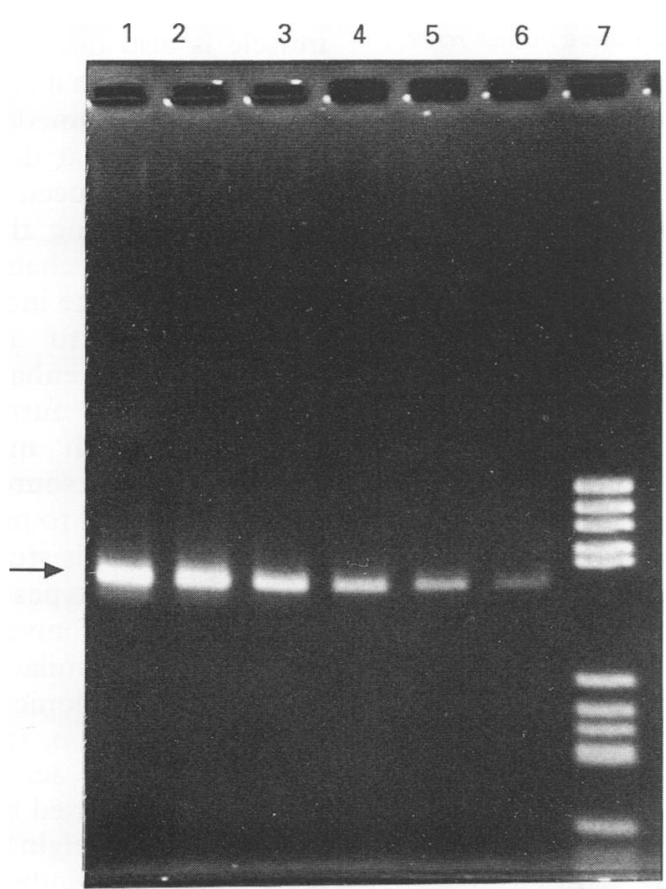

Figure 3: Concentration dependent amplification of ICOM-1 fragment by 31 cycles. Lanes $1,2,3,4,5$, and 6 contain respectively twofold serially diluted samples of 100 , $50,25,12 \cdot 50,6 \cdot 25$, and $3 \cdot 125$ of ICOM- 1 . Lane 7 contains PBR322 $\times$ HaeIII DNA size marker (Sigma). The position of ICOM-1 is indicated by the arrow.

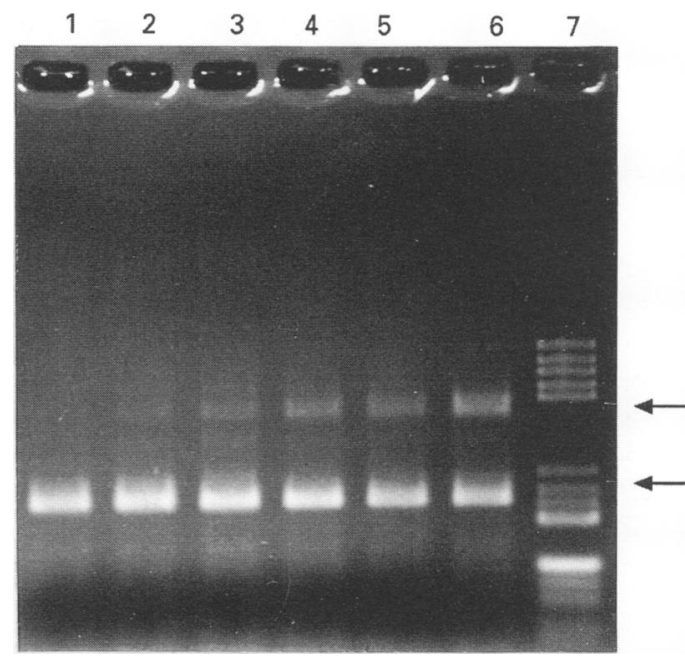

Figure 4: Gel showing the concentration dependent PCR amplification of the ICOM-1 fragment with $500 \mathrm{ng}$ rat total RNA by 31 cycles using PR3 and PR4 primers. Lanes $1,2,3,4,5$, and 6 contain $3 \cdot 125,6 \cdot 25,12 \cdot 5,25,50$, and 100 of ICOM-1 respectively. Lane 7 contains

PBR322 $\times$ HaeIII DNA size marker (Sigma). The positions of IL-1 $\beta$ (lower arrow) and ICOM-1 (upper arrow) are shown.

tration dependent amplification, whereas the level of IL-1 $\beta$ mRNA remained unchanged, suggesting that the ICOM-1 control (391 bp) can be amplified with the IL-1 $\beta$ mRNA (214 bp) in biological samples (Fig 4). Figure 5 shows cycle dependent amplification of $25 \mathrm{ng}$ of ICOM-1 and $250 \mathrm{ng}$ total RNA, suggesting that the method presented here is applicable over a broad range of cycle settings and can be further adapted for any application by adjusting the amount of cDNA or cycle numbers. In order to obtain quantitative evaluation of these results, the areas of the bands from the negatives were obtained by scanning on a densitometer, Pharmacia, LKB (data not shown). Thus from these experiments we selected $25 \mathrm{ng}$ of ICOM-1 and 100-250 ng total RNA sample for linear range amplification of IL-1 $\beta$ mRNA in muscle samples.



Figure 5: Cycle dependent PCR amplification of $25 \mathrm{ng}$ ICOM-1 and 250 ng of rat total RNA by 30 (lane 1), 33 (lane 2), 36 (lane 3), 38 (lane 4), and 40 (lane 5) cycles with PR3 and PR4 primers. Positions of IL-1 $\beta$ PCR fragment (lower arrow) and ICOM-1 (upper arrow) are shown. Left flanking lane (100 bp DNA ladder) and right flanking lane (PBR322 $\times$ HaeIII) contain DNA size markers. 


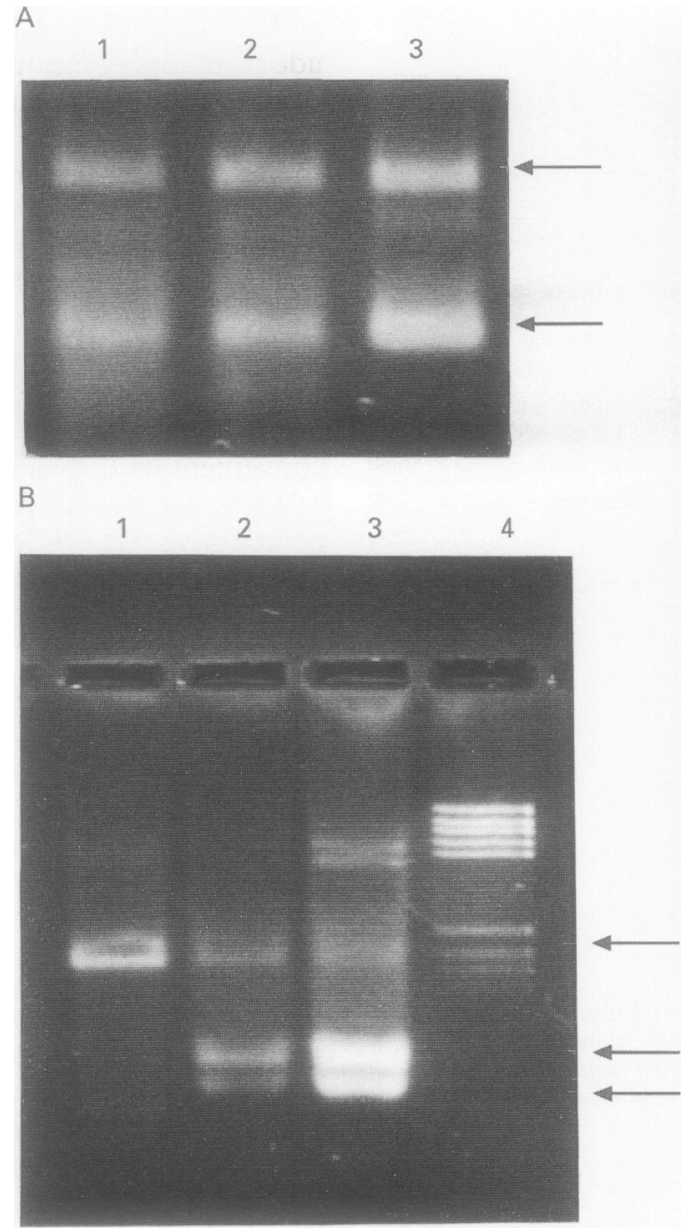

Figure 6: (A) Species specificity of the PR3 and PR4 primers. 25 ng ICOM-1 was amplified with 500 ng total $R N A$ from humans (lane 1), mouse (lane 2), and rat (lane 3) using PR3 and PR4 primers. Arrows indicate the positions of ICOM-1 (upper) and IL-1 $\beta$ (lower) PCR fragments. (B) BamH1 digestion patterns of IL-1 $\beta$ PCR fragment (214 bp) from humans (lane 1), mouse (lane 2), and rat (lane 3). The position of $214 b p I L-1 \beta$ PCR fragment is shown by the upper arrow. The fragments 119 $b p$ (middle arrow) and $95 \mathrm{bp}$ (lower arrow) which resulted from BamH1 digestion of $214 \mathrm{bp}$ (upper arrow) are shown (lane 2, 3). Lane 4 contains PBR322 $\times$ HaeIII size marker (Sigma).

Further, we evaluated the specificity of the primers PR3 and PR4 in different species including humans, mice, and rats. PR3 and PR4 primers amplified a 214 bp fragment from the total RNA obtained from humans (Fig 6A, lane 1), mice (Fig 6A, lane 2) and rats (Fig 6A, lane 3), which was confirmed by BamH1 restriction analysis. The mouse IL-1 $\beta$ fragment contained a BamH1 site which cut the $214 \mathrm{bp} \mathrm{IL-1 \beta}$ PCR fragment into $119 \mathrm{bp}$ and 95 bp pieces (Fig 6B, lane 2), whereas the human IL-1 $\beta$ PCR fragment did not contain the BamH1 site (Fig 6B, lane 1). In rats (Fig $6 \mathrm{~B}$, lane 3), BamH1 produced fragments of the size similar to the mouse, suggesting that the structure of IL-1 $\beta$ is similar in rats and mice.

PROFILE OF IL-1 $\beta$ IN COLONIC MUSCLE

The level of IL-1 $\beta$ mRNA was estimated using the present PCR method in the RNA samples (Fig 7A). There was constitutive expression of IL-1 $\beta$ mRNA in the colonic muscle of the untreated control rats (Fig 7B, lane 1) which increased significantly one (Fig 7B, lane 2), two (Fig 7B, lane 3) and five days (Fig 7B, lane 4) after acetic acid administration. The level of IL-1 $\beta$ mRNA after seven days (Fig 7B, lane 5) of acetic acid administration was comparable with the basal level. Each RNA sample was spiked with $25 \mathrm{ng}$ purified ICOM-1 DNA. The bands corresponding to IL-1 $\beta$ (214 bp) and ICOM-1 (391 bp) on the negatives were $\stackrel{\vec{\rho}}{\vec{\rho}}$ scanned on a densitometer (Pharmacia, LKB) to obtain the area of each band. The ratio 흘

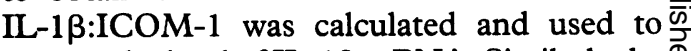
express the level of IL-1 $\beta$ mRNA. Similarly the $\stackrel{\overparen{\Phi}}{\varrho}$ internal control, $\beta$-subunit of sodium pump, ${ }^{14} \mathrm{~N}$ was also amplified from each sample (Fig 7C) $\vec{\circ}$ and the ratio IL-1 $\beta: \beta$-subunit calculated. The data obtained with the present PCR method $\vec{\omega}$ were compared with those obtained using the $\beta$-subunit of sodium pump mRNA. As the Table shows, increases in the level of IL-1 $\beta$. mRNA obtained by these controls were com- $\omega$ parable. The increase in the level of IL-1 $\beta$ 이 mRNA after five days of acetic acid adminis-o tration was not suppressed by indomethacin? treatment of the rats (data not shown).

\section{Discussion}

Intestinal inflammation is accompanied by $\stackrel{\oplus}{-v}$ hyperplasia, hypertrophy, and muscle hyperresponsiveness. ${ }^{20} 21$ These changes in the muscle may be influenced by inflammatory mediators such as IL- $1 \beta$ released either from the inflammatory cells or produced by the muscle cell itself. $^{22}$ It is known that IL-1 $\beta \vec{\Rightarrow}$ induces the proliferation of human intestinal 3 smooth muscle cells ${ }^{7}$ and mediates release of neurotransmitter from the myenteric plexus. In addition, IL-1 $\beta$ causes relaxation of vascularo muscle ${ }^{8}$ and is known to inhibit gastrointestinal motility in vitro. ${ }^{23}{ }^{24}$ As the contractility of the muscle is also decreased during colitis, ${ }^{29}$ weके expected to see an increase in the level of IL-1 $\beta$ 곡 mRNA in inflamed colonic muscle. Our findings show that the level of IL- $1 \beta$ mRNA expression is induced significantly in inflamedo muscle, suggesting that IL-1 $\beta$ is a putative mediator of the changes in muscle function during colitis. The induction of $\mathrm{mRNA}$ which 0 may be due to an enhanced rate of transcription or enhanced stability of IL-1ß0 mRNA needs further study. Althougho intestinal smooth muscle cells have beeno shown to act as a source of and a target for IL $\rightarrow$ $1 \beta,{ }^{22}$ it is difficult to predict the cellular source of IL-1 $\beta$ from this study because muscle use contains various types of cells.

The profile of myeloperoxidase activity in $\stackrel{\mathbb{\Omega}}{\Omega}$ the colon was similar to the profile of IL-1 mRNA in the colonic muscle in this model of colitis. In addition, increases in the levels of myeloperoxidase activity and IL-1 $\beta$ mRNA were not suppressed by the indomethacin (10. $\mathrm{mg} / \mathrm{kg}$ body weight) treatment (data not shown). These findings suggest that arachidonic metabolites may not be the chemotactic agents for the induction of IL- $1 \beta$ or infiltration of neutrophils. Nevertheless, we conclude that IL-1 $\beta$ may be considered to be a potential marker of inflammation. 
A
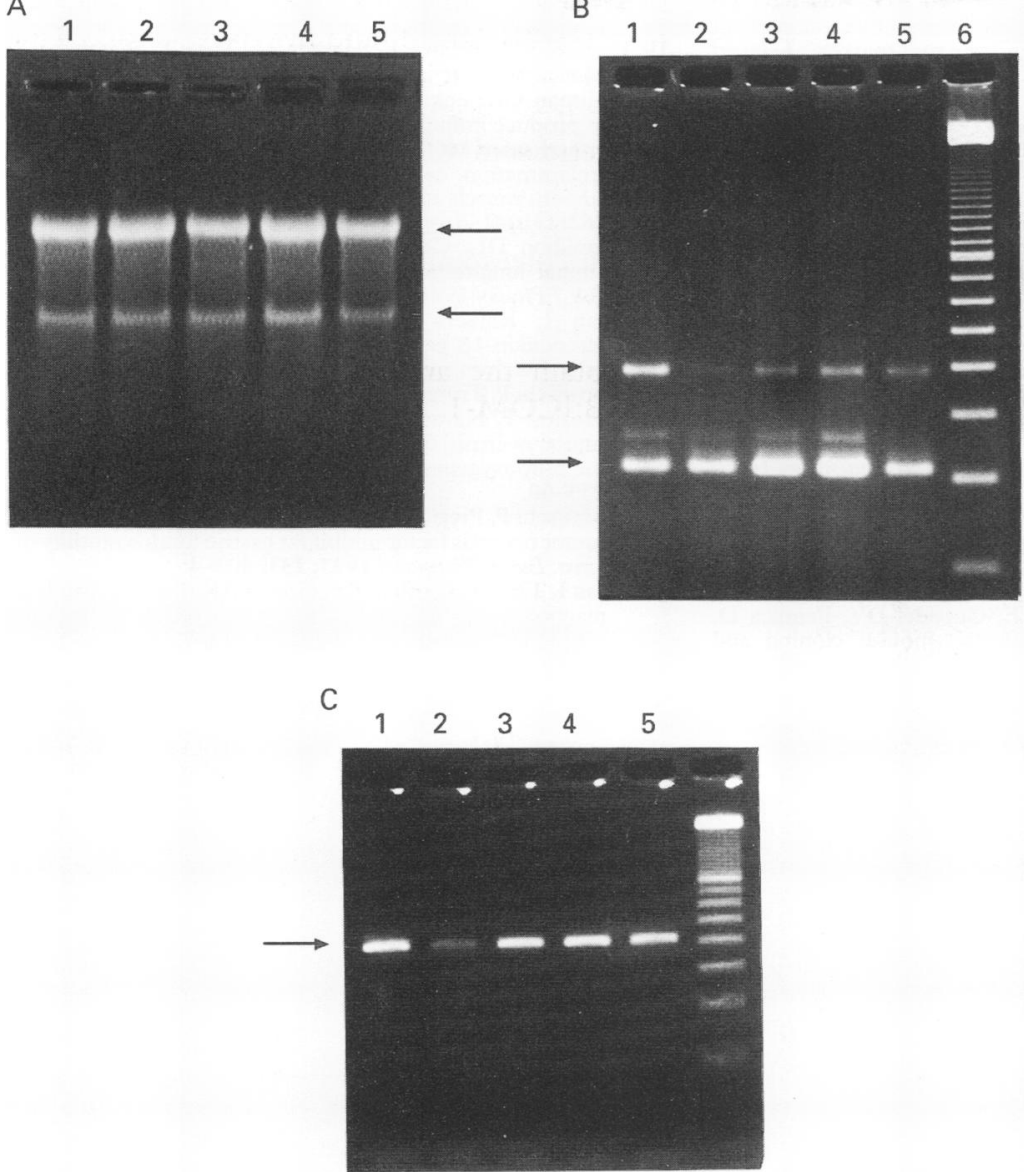

Figure 7: (A) Gel showing quality of total RNA extracted from colonic muscle of control rats (lane 1), and from the rats after one (lane 2), two (lane 3), five (lane 4), and seven (lane 5) days of acetic acid administration. Each lane contains $5 \mu \mathrm{g}$ total $R N A$. The positions of $28 s$ (upper arrow) and $18 s r R N A$ (lower arrow) are shown. (B) Gel showing amplification of IL-1 $\beta \mathrm{mRNA}$ and ICOM-1 control by 30 cycles of PCR. Each lane shows the level of $I L-1 \beta \mathrm{mRNA}$ in equivalents of $100 \mathrm{ng}$ of total $R N A$ from colonic muscle of control rats (lane 1) and after one (lane 2), two (lane 3), five (lane 4), and seven (lane 5) days of acetic acid administration. Lane 6 shows 100 bp DNA ladder (Pharmacia). Each lane contains $25 \mathrm{ng}$ of ICOM-1 control DNA. Arrows indicate the position of ICOM-1 (upper) and IL-1 $\beta$ (lower). (C) Gel showing amplification of $\beta$-subunit $m R N A$ of sodium pump by 21 cycles of PCR. Each lane shows the level of $I L-1 \beta \mathrm{mRNA}$ in equivalents of 100 ng total RNA from colonic muscle in the control rats (lane 1) and after one (lane 2), two (lane 3), five (lane 4), and seven (lane 5) days of acetic acid administration. Unlabelled lane shows DNA size marker (100 bp DNA ladder; Pharmacia). Arrow indicates the position of $\beta$-subunit PCR fragment.

Although RT-PCR is a very sensitive method, slight variation in the efficiency of the amplification may magnify errors tremendously. ${ }^{25}$ Therefore, a control is usually coamplified with the target molecule to monitor the sample to sample variability during amplification. Although various "housekeeping" genes have been used as internal controls in different RT-PCR methods, a huge difference in the abundance of the housekeeping gene and the target molecule often makes it difficult to

Percentage increases in IL-1 $\beta m R N A$ after acetic acid treatment

\begin{tabular}{llll}
\hline & \multicolumn{4}{l}{ Increase (\% control) in the level of IL-1 $\beta$ mRNA } \\
\cline { 2 - 4 } Days after treatment & $I L-1 \beta: I C O M-1(A)$ & $I L-1 \beta: \beta$-subunit $(B)$ & $p$ Value $(A \mathrm{v} B)$ \\
\hline 0 & 100 & 100 & \\
1 & $300(124)$ & $184(5)$ & $0 \cdot 120$ \\
2 & $255(59)$ & $207(45)$ & 0.438 \\
5 & $305(74)$ & $242(25)$ & $0 \cdot 121$ \\
7 & $120(50)$ & $71(28)$ & 0.438 \\
\hline
\end{tabular}

Each value is the mean of duplicate determinations of two pooled preparations each from five animals. The area of the PCR bands was calculated using negatives. Statistical analysis was performed using SPSS software. achieve their relative amplification. In addition, under various pathophysiological and developmental conditions, the level of these housekeeping genes may also change and therefore, such internal controls cannot be suitable for mRNA measurement. Therefore, these PCR methods have severe limitations.

The competitive PCR methods are considered to be the most reliable techniques of mRNA measurement. In addition, for each species a separate competitive control is needed; therefore there is no suitable and convenient method for the estimation of IL-1 $\beta$ mRNA. In this study we have developed a competitive RT-PCR method which can be used to quantify the level of IL-1 $\beta$ mRNA in rats, mice, or humans with the same control. We also validated our findings with another internal control, the $\beta$-subunit of sodium pump which produced comparable data (Table). Thus the increases in the level of IL$1 \beta$ mRNA shown are specific and do not reflect variations of amplification. Furthermore, the yield of total RNA from colitis tissues was not significantly different from the untreated control rats (data not shown) and the quality of each total RNA sample was also comparable (Fig 7A). These findings taken together support the conclusion that the changes in the level of IL- $1 \beta$ mRNA reported in this study are real and specific.

In conclusion, we showed that the expression of IL-1 $\beta$ mRNA is enhanced in colonic muscle during colitis induced by acetic acid. To our knowledge this is the first report showing enhanced production of IL- $1 \beta \mathrm{mRNA}$ in colonic muscle in this model of colitis. We speculate that this is a putative mediator of the changes in muscle growth and function. We also established that the current RT-PCR method developed for this work is reliable, convenient, and can be used in a wide variety of animal species including rats, mice, and humans.

We gratefully acknowledge Professor R Grasbeck, Dr HR Fatania for their valuable comments and suggestions, Ms N Thomas for technical help, and Professor M Ali for his kind gift of indomethacin.

1 Andrew JW, Ekbom A, Dhillon AP, Pittilo RM, Pounder RE. Crohn's disease: pathogenesis and persistent measles Crohn's disease: pathogenesis and persistent
virus infection. Gastroenterology 1995; 108: 911-6.

2 Snape WJ Jr, Williams R, Hyman PE. Defect in colonic smooth muscle contraction in patients with ulcerative colitis. Am f Physiol 1991; 261: G987-91.

3 Collins SM, Blennerhassett PA, Blennerhassett MG, Vermillion DL. Impaired acetylcholine release from the myenteric plexus of Trichinella-infected rats. Am $\mathcal{F}$ Physiol 1989; 257: G898-903.

4 Khan I, Collins SM. Expression of cytokines in the longitudinal muscle myenteric plexus of the inflamed intestine tudinal muscle myenteric plexus of the inflam
of rat. Gastroenterology 1994; 107: 691-700.

5 Dinarello CA. The interleukin-1 family: 10 years of discovery. FASEB f 1995; 8: 1314-25.

6 Main C, Blennerhassett P, Collins SM. Human recombinant interleukin $1 \beta$ suppresses acetylcholine release from rat myenteric plexus. Gastroenterology 1993; 104: 1648-54.

7 Owens MW, Grisham MB. Cytokines increase proliferation of human intestinal smooth muscle cells: possible role in inflammation-induced stricture formation. Inflammation 1993; 17: 481-7.

8 Marceau F, Petitclerc E, DeBlois D, Pradlelles P, Poubelle PE. Human interleukin-1 induces rapid relaxation of the rabbit isolated mesenteric artery. Br f Pharmacol 1991; rabbit isolated

9 Grossi L, McHugh K, Collins SM. On the specificity of altered muscle function in experimental colitis in rats. Gastroenterology 1993; 104: 1049-56.

10 McPherson BR, Pfeiffer CJ. Experimental production of diffuse colitis in rats. Digestion 1993; 17: 135-50. 
11 Bradley PP, Priebat DA, Christensen RD, Rothstein G. Measurement of cutaneous inflammation: estimation of neutrophil content with an enzyme marker. $\mathcal{F}$ Invest Dermatol 1982; 78: 206-9.

12 Chirgwin JM, Przybyla AE, MacDonald R, Rutter WJ. Isolation of biologically active ribonucleic acid from sources enriched in ribonuclease. Biochemistry 1979; 18: 5294-9.

13 Maniatis T, Fritsch EF, Sambrook J. Molecular cloning. Cold Spring Harbor, New York: Cold Spring Harbor Spring Harbor, New

14 Khan I, Collins SM. Altered expression of sodium pump isoforms in the inflamed intestine of Trichinella spiralisinfected rats. Am $\mathcal{F}$ Physiol 1993; 264: G1160-8.

15 Innis MA, Gelfand DH, Sninsky J, White TJ. PCR protocols: a guide to methods and applications. New York: Academic Press, 1990.

16 Khan I, Kataeva G, Blennerhassett M, Collins SM Interleukin- $1 \beta$ induces the expression of interleukin- 6 in Interleukin-1 $\beta$ induces the expression of interleukin-6 in 108: $1720-8$.

17 March CJ, Mosley B, Larsen A, Cerretti DP, Braedt G, Price V, et al. Cloning, sequence and expression of two distinct human interleukin-1 complementary DNAs. Nature 1985; 315: 614-48.

18 Gray PW, Glaister D, Chen E, Goeddel DV, Pennica D. Two interleukin 1 genes in the mouse: cloning and expression of the cDNA for murine interleukin $1 \beta . \mathcal{f}$ Immunol 1986; 137: 3644-8.

19 Himunol 1986; 137: Matsuda T, et al. Complementary DNA for a novel human interleukin (BSF-2) that induces B lymphocytes to produce immunoglobulin. Nature 1986; 324: 73-6.

20 Blennerhassett MG, Vignjevic P, Vermillion DL, Collins SM Inflammation causes hyperplasia and hypertrophy in smooth muscle of rat small intestine. Am F Physiol 1992 262: G1041-6.

21 Vermillion DL, Collins SM. Increased responsiveness of jejunal longitudinal muscle in Trichinella-infected rats. jejunal longitudinal muscle in Trichinella-infected rats. Am f Physiol 1988; 254: F124-G129. Auto-induction of

22 Khan I, Kataeva G, Collins SM. Auto-induction of interleukin-1 $\beta$ gene expression in enteric smooth muscle
cells. Gastroenterology 1993; 104: A534.

23 Montuschi P, Tringali G, Curro D, Ciabattoni G, Parente L, Preziosi P, Navarra P. Evidence that interleukin- $\beta$ and tumor necrosis factor inhibit gastric fundus motility via the 5-lipoxygenase pathway. Eur $\mathcal{F}$ Pharmacol 1994; 252: 253-60.

24 Montuschi P, Preziosi P, Navarra P. Interleukin-1 alpha and tumor necrosis factor inhibit rat gastric fundus motility in- 0 tumor necrosis factor inhibit rat gastric fund

25 Khan I, Tabb T, Garfield RE, Grover AK. Polymerase chain $\vec{\omega}$ reaction assay of mRNA using $28 \mathrm{~s}$ rRNA as internal o standard. Neurosci Lett 1992; 147: 114-7. 